\title{
Arbitration and Law in Renaissance Florence
}

\author{
THOMAS KUEHN
}

Arbitration and other extrajudicial forms of dispute settlement are only beginning to receive serious consideration in historical studies. Long relegated to an intermediate position in the presumed progression from violent self-help to the sophisticated machinery of a state-run judicial system, arbitration seemed to hold little historical interest. It lacked formal procedures and conceptual sophistication. Its contribution to legal history, therefore, was minimal, so arbitration received only brief treatment in histories of civil procedure. ${ }^{1}$ Political and social history also neglected arbitration, which was seen as contributing little to the formation of effective government and social order. Arbitration, it was assumed, flourished only where and when government was too weak to provide truly effective order. $^{2}$

Historians utilizing local sources in areas of continental Europe and England have begun to take stock of the persistence and vitality of arbitration alongside the law. This persistence is taken as indicative not so much of shortcomings in the formal judicial system but of."a vigorous and durable tradition of extrajudicial settlement." ${ }^{\text {"3 }}$ Recognition has been accorded to the role played by canon law in setting the place of arbitration in a legal order. ${ }^{4}$ The needs of city residents and governments have been singled out as formative for legal arbitration. ${ }^{5}$ It has also become apparent that litigation and arbitration were not mutually exclusive. Many suits were initiated to culminate not in formal adjudication but in a compromise settlement. The lawsuit was not an end in itself but a form of leverage to force a settlement, ${ }^{6}$ at times with the encouragement of the judge. ${ }^{7}$ The intent of this paper is to investigate the relationship between arbitration and law in one city, Florence, focusing in the end on a judicial case concerning arbitration.

Anthropology has powerfully informed this historical revision regarding arbitration. Especially important is the anthropological concept of dispute as a normal, not pathological, stage in ongoing social relationships. Legal anthropologists have also erected typologies of dispute settlement 
mechanisms and social structures. ${ }^{8}$ The presence of a third party in the dispute process and the extent and origin of his authority are integral to these typologies. But in tribal or "traditional" societies parties have "multiplex" relationships. Insofar as a dispute is part of a relationship, it has origins and implications far beyond any one factual or normative issue. Mediation and/or arbitration provide means of striking a new "balance," of continuing a relationship important to both parties and to others close to them. The imposition of rules, the achievement of some abstract ideal of justice that grounds a normative order are not desirable here, according to anthropologists. Rather the maintenance of social order demands compromise. The winner-take-all of formal adjudication is considered to fit the situation of modern capitalistic society where relationships are onedimensional, utilitarian, oriented to an impersonal market - the sort of relationships that can besacrificed in litigation. ${ }^{9}$ In court the judge subordinates everything to a simple issue of law; he does not inquire broadly into the relationship before him. ${ }^{10}$ So historians have stated that the more flexible, less rule-bound procedures of arbitration could "perform functions to which the courts could not aspire: they could settle feuds, make peace and restore harmonious social relations between disputing neighbors." Arbitration "might often be more effective than the legal process in reaching a final settlement which both sides regarded as equitable." 11 The arbitrators'

function was not that of a law court, to decide in favor of one party or another on the basis of a body of legal rules and principles. Legal thinking might influence their deliberations, but ... arbitrators were concerned less to apply objective rules of decision than to ensure that both parties were satisfied and that no one left emptyhanded. ${ }^{12}$

Because arbitration took into account whole relationships and their contexts, rather than just a few relevant rules, it served to reconcile the parties and recreate durable social ties. "Such compromises were therefore regarded as being if anything, firmer, more binding and more just than the court judgments that might sometimes have been rendered in the same cases."13

Arbitration and law thus end up, or remain, in both ethnographic and historical analyses, as functional opposites: one intent on restoring peace, the other on doing justice. The functional explanations of anthropology, borrowed wholesale into legal and social history, leave one wondering no longer about how arbitration was able to persist, but rather about how law was able to make any headway against it, until social structure changed independently. Careful examination of the historical record - or at least the part of it presented below - will show, however, that the dichotomy between law and arbitration was not so great, especially in the late Middle 
Ages. To do justice could also be to restore peace, or to take an effective step in that direction. In distinguishing between justice and peace, we must be on guard against an ethnocentric assumption. It was a medieval maxim that "pactum legem vincit et amor judicium." 14 The distinction between agreement and law, between love and judgment, animated a good deal of medieval theorization of and recourse to arbitration, to be sure. But not only does the same set of distinctions not necessarily apply to dispute processing in nonwestern societies, it does not imply a thorough separation of law and arbitration in western history. ${ }^{15}$

It may be that law contributed to arbitration. At least one anthropologist, noting that those who wish to avoid agents of the state avail themselves of arbitrators, has been moved to remark that "arbitration generally grows up in the shadow of adjudication, rather than the other way round." 16 Only "once state procedures were crystallized, private agreements could be seen as more flexible." 17 Certainly in the Middle Ages arbitration was formalized in canon law and bore the "unmistakable imprint of legal thought and practice." 18 At least one legal historian has arguedthat the inadequacies of academic law led to the use of arbitration and subsequent doctrinal developments that attempted to keep up with practice. ${ }^{19}$ Oral arguments and written proof, testimony of witnesses, bonds for performance, setting of dates for awards, and other aspects of arbitration processes testify to the successful influence of law. In arbitration, as in adjudication and unlike mediation, the parties relinquish control over the decision to a third party. ${ }^{20}$ Nor was, then as now, arbitration played out without reference to norms, even highly complex ones of professional law.

In negotiatory processes, as in those of adjudication, disputants and third parties organize their arguments around normative propositions. These may be more or less explicit and clear-cut, and are unlikely rigidly to determine an outcome; but they will inform the arguments and play some part in the outcome that is reached.21

The parties have to make their dispute intelligible in normative terms to others. They may mask the true nature of their dispute, or they may be incapable of giving it an accurate formulation; but they must make the effort.

Here is where the functionalist account of arbitration and law most clearly reveals its shortcomings. The litigants' or disputants' circumstances, their interests, and the pertinent norms were not always clear. They were riddled with indeterminacies, ambiguities, uncertainties. Ambiguities made for disputes, and they were not always easily resolvable. Some were just too complex. ${ }^{22}$ Coercion and fraud were also possible in arbitration. ${ }^{23} \mathrm{We}$ have to be attuned to the possible dysfunctions or even total failures of arbitration, in addition to its undoubted functional potential in terms of the culture 
in which it operated. Finally, it has to be acknowledged that the sanctions available to enforce observance of the provisions of an arbitration included court intervention. An arbitration agreement did not necessarily mean the end of a dispute.

The widespread imitation of the precise legalistic formulae of canon-law arbitration, suitably adapted for the requirements of the common law [but also of civil law and local statutes], implies a recognition on the part of disputants that a settlement made out of court would only endure if it proved unassailable to a subsequent challenge in court. The resources of the law were thus harnessed to provide support and protection for arbitration. ${ }^{24}$

Arbitration may have been more appropriate to restore a state of peace between parties, but more formal public procedures could fashion a more comprehensive conclusion to a dispute, ${ }^{25}$ so arbitrations were written down with all the notarial solemnities of contracts, testaments, and other legal acts to establish the terms of compliance and their actionability, if needed, in a court of law. ${ }^{26}$ It is precisely this point - the contesting of an arbitrated settlement in court - that this paper will explore. After preliminary consideration of relevant legal and social factors, we will examine court cases, one in particular that surfaced in Florence in 1411. The value of working on Florentine materials - beyond the economic, political, and cultural importance of the city - lies in the fact that, as a civil law jurisdiction, Florentine statutory law provides a context as yet unexamined with regard to arbitration. ${ }^{27}$

\section{Arbitration in Florence and Its Statutes}

Medieval legal doctrines regarding arbitration revolved around two terms - arbiter and arbitrator. The prevailing view has been that these two terms simply represented different procedural forms always present in the law. The arbiter decided according to law, following a judicially imitative procedure. The arbitrator, on the other hand, was an amicabilis compositor who operated without reference to norms or set procedures but solely on the basis of a more vague but flexible equity. ${ }^{28}$ Recent research by Luciano Martone has revealed that, contrary to previous views, these two terms did not arise simultaneously and were not simply facets of a dialectic between law and equity. Arbitrator was not a term known to or explored by the glossators, whereas arbiter had been part of Roman law and was visible in the texts of the Corpus iuris civilis. Arbitrator came to prominence only with the postglossators, such as Guglielmo Durante (d. 1295), whose enormously influential Speculum iudiciale set the tone followed by jurists like Giovanni d'Andrea (d. 1348), Bartolo da Sassoferrato (d. 1357), and Baldo degli Ubaldi (1327-1400) in discussions of arbitration. To Durante the 
arbitrator differed from the arbiter not only on the basis of a distinction between equity and law but also on the fact that he did not have the decisional powers of the arbiter to consider the merits of the case but merely could arrange certain factual matters committed to him by the parties - contractual matters generally - in the interests of peace between them.$^{29}$ The arbitrator first arose in practice. It was the notaries who took the lead in establishing legal formulae that distinguished the arbitrator from the arbiter ${ }^{30}$ The powers of both arbitri and arbitratores were voluntary. They were chosen by the parties, who placed themselves under their determination at the time of election in a contract of compromissum. In all cases the person to whom the parties had committed their differences was bound to decide on his own; he could not delegate the task to another ${ }^{31}$ There were no firm procedural guidelines, though the expectation was that the arbiter would imitate formal judicial proceedings, while the arbitrator would operate more informally - "arbitrator est qui consilio suo tamquam bona fide, et bono motu, nulla iuris solumnitate servata absque iudiciorum strepitu litem decidit," in the formulation of Bartolo. ${ }^{32}$ Enforcement of the settlement lay with the parties. In the contract of compromissum, in which they agreed to submit to binding arbitration and named the arbitrators, the parties also established a monetary penalty on each other for noncompliance. Provision of a penalty was an important validating device. If nopenalty had been set, the arbitration was valid only if the parties agreed to it in writing or kept silence for ten days. In essence enforcement mechanisms and problems were similar to those for most other forms of contract.

Aside from enforcement was the problem of the validity of the arbitrator's determination and the admissibility of means to modify or annul it. There was in theory no recourse from an inequitable decision of an arbiter. The parties had, by choosing him, an obligation to accede to his decision, which was limited to the matter placed before him by them. ${ }^{33}$ Only an exceptio doli on the grounds of the arbiter's malfeasance was allowed against a sentence. ${ }^{34}$ An arbiter was thus an agent in a generally private and voluntary context; he had no jurisdiction and so his sententia had no binding force..$^{35}$ It could not stand as a precedent for others or affect the legal rights or abilities of those not party to it. ${ }^{36}$ It could not even bind the parties themselves, except insofar as they had bound themselves by the monetary penalty for noncompliance. Thus there could be no appeal, in the strict sense; although some jurists were willing to contemplate appeals of arbitration on the grounds of violation of law, if not equity (contra ius). ${ }^{37}$

In contrast to the inappellability of the arbitrium of an arbiter, the findings of an arbitrator could undergo a sort of appeal. The informality of the arbitrator tended to push the arbiter, in the minds of the jurists, into the same camp with the iudex - as operating within strictum ius and with a 
formalized and largely written procedure utilizing a libellus of charges or claims, the hearing of witnesses, granting delays, and resolving all normative and factual elements. The arbitrator, however, sought a more indefinite aequitas with no set procedure, and, though his competence was supposedly limited to narrow factual questions, any resulting inequity had to be remedied. So here a disgruntled party could appeal to another's judgment - arbitrium boni viri. ${ }^{38}$ The arbitrator issued not a sententia, not an arbitrium, but a laudum or arbitramentum - a form of transaction..$^{39}$ The parties had sought an equitable basis to their relationship, so they were entitled to reascertain that basis by appeal to a "good man." 40 In the manner of a syndication of a communal officeholder, the bonus vir could not modify the act of the arbitrator, he could only annul it after examining the relation between the contents of the compromissum and the laudum. ${ }^{41}$ The parties expressed desire for equitable concord, rather than their previous state of conflict, became the basis to arbitration in the eyes of jurists, so "the reductio constituted a final guarantee of the intentions embodied in the recourse to arbitration." 42

While scholastic legal doctrines kept the distinction between arbiter and arbitrator, notarial and statutory practice elided them. ${ }^{43}$ Notaries, who also often served as arbitrators, ran the terms together in their redactions of arbitrated settlements. ${ }^{44}$ As Linda Fowler has argued, this may have allowed for maximum flexibility: the parties left procedure to the mediating third party and only after the fact, if one of them chose to challenge the outcome, was it necessary to distinguish and define, on the basis of the procedures followed, whether the third party had acted as anarbiter or as an arbitrator. ${ }^{45}$ Or it may also be, as Martone has it, that the procedural and equitative flexibility of the arbitrator was enlarged over the areas of wider than factual competence belonging to the arbiter $^{46}$

In hopes of peaceful settlement of differences among citizens, many Italian cities inserted arbitration into the range of statutorily available legal procedures. ${ }^{47}$ While indiscriminately using terms like sententia and laudum, cities' statutes were nonetheless giving arbitrated settlements legal sanction. Arbitration was generally made available to anyone, and anyone with full legal capacity (therefore, not minors, women, or slaves) could serve as arbiter or arbitrator. ${ }^{48}$ But arbitration was especially made available by statute for disputes among close relatives. That disputes would arise between relatives would not be surprising because property rights and obligations, as well as honor, were implicated in such relationships. The statutes did not visualize atomistic individuals but molecular groups held together by blood and law. The ideology of kinship solidarity made it imperative that disputes between close kin not get out of hand - not become violent and public (not that some did not). ${ }^{49}$ The government, through its laws, was supposed to promote the continued existence and 
well being of families, which were seen as its structural basis and, in governmental paternalism, as its functional model. ${ }^{50}$

The statutes of Florence were fairly typical in their treatment of arbitration - typical even in their confusion. The core of Florentine legislation concerning arbitration, and the point where it most directly touched the judicial apparatus, lay in a statute entitled "Quod consanguinei et consortes habentes questionem vel controversiam teneantur ipsam commictere" in the 1355 statutes of the Podestà. ${ }^{51} \mathrm{~A}$ smorgasbord of relatives in male and female lines, including bastards, within about four degrees of relationship (cousins, grandparents) but even "usque in infinitum," were judicially enjoined "ad requisitionem alterius partis" to elect "arbitros et arbitratores." They had eight days, no right to cite exceptions or seek the consilium of a sapiens, and faced a fine of 300 lire for failure to do so. Each party chose one (or more if they had so agreed) and gave guarantees that he/they would abide by the subsequent ruling.52 The arbitri or arbitratores (presumed usually to be other consanguinei) had two months to reach a decision or face a 100 lire fine levied on them by the Podestà; and even then they still had to pronounce a judgment. The Podestà could, after two months, give the arbitrators another month to name a third, thus breaking the tie and establishing majority rule. The third could thus be seen as an arbitrator between two discordant arbitrators. ${ }^{53}$ The judge was to safeguard against inequality or deception in the selection process, and, if the parties could not agree in formulating the charge to the arbitrators to be embodied in a written compromissum, he was to appoint a "iurisperitus" to do so, whose formulation could not be opposed or appealed.

Judges were enjoined to enforce all such compromissa, lauda, and sententiae, even to the point of jailing someone at the bidding of the other party. Nonperformance of stipulated payments was to meet with a fine of two soldi per lira $(10 \%)$. Women could not beforced to arbitration concerning their dowries. And no one could be compelled to compromise the same matter twice. But neither could a mere promise not to go to arbitration keep one from enjoying the benefit of this statute - that according to an addition first enacted in 1324. Such a promise was invalid.

The legislative situation prevailing from 1355 reveals several interesting things. The lack of definition of terms shows an assumed reliance on prevailing norms of the "common law" of the schools. Arbitration was also set into the statutes only in the context of disputes among kin, seeking to ease such disputes out of court and to confine them (in their formulation, if not in their total enforcement) to kin. Notions of equity surface in the statute, not notions of strict literalistic legality. The resulting laudum was thus distinguished from the decision that would have been rendered had the case remained in court. ${ }^{54}$ Peace, or at least reestablishing a working relationship among the parties, seemed to underwrite this law. Above all, as Martone 
has pointed out, this and other statutes like it did not change the essentially private nature of arbitration. Statutes could demand a move from litigation to arbitration only when one of the parties made kinship to the other an issue. Naming the arbitrators always lay with the parties themselves, as did setting the issue(s) for them. The statutes set fines and time limits to hurry along the process, allowed maximum flexibility and speed by conjoining the powers of arbiter and arbitrator, and inserted it all into the judicial order by guaranteeing enforcement. ${ }^{55}$ In seeking a speedy conclusion to conflicts the statute also foreclosed appeals of arbitrators' lauda, except in the form of the reductio. To allow new evidence and issues to be introduced in a full-blown appeal would not further the cause of equity. ${ }^{56}$

The fact that arbitration was more generally part of the legal system, a permanent part of notarial practice, and an increasingly useful institution hardly seems evident from the 1355 statutes. In 1415 the institution was legislatively decked out in a very different and more comprehensive manner. The jurists Paolo di Castro (c. 1360-1441) and Bartolomeo Vulpi da Soncino (c. 1359-1435) reworked the existing statute and intervening provisions in light of judicial practice. The rubric "De compromissis fiendis inter consortes" substantially resembled the 1355 statute, but it also contained important revisions as well as a careful tightening up of its language. ${ }^{57}$ Gone was the lengthy spelling out of the process by which a third arbitrator would be selected. In its place was simply a brief reference to the fact that one would be chosen "a principio simul." Also omitted was reference to the fine for nonpayment. Added to the statute were clauses specifying that the move out of litigation into arbitration had to come before the probative stages of the judicial procedure (once into the evidence one could not be forced to arbitration), that no one could be forced to arbitrate what had been judged "per aliquod officium, consulatus, vel officialem, vel sex mercantie," that no one could deny kinship to avoid a compromise. ${ }^{58}$ Also there was a provision that no one could move against a decision by renunciation of the agreement to compromise unless he did so by a public instrument. This was followed by the general observation:

And by the form of the present statute a compromise may be sought and must be sought once and many times and as often as will be opportune, until the questions and controversies thus compromised will be decided and terminated, save always the already disposed.

This preservation of existing judgments and setting of limits as to when a case could be removed into arbitration from litigation was designed to preclude undue delays and shady tactics. Di Castro and Vulpi may have been familiar with a case handled by the noted Bolognese lawyers Pietro d'Ancarano (c. 1330-1416) and Floriano da San Pietro (fl. 1400), a copy of which 
is preserved in a Florentine manuscript. In that case a man and his son had repudiated his father's estate in favour of his brother, but with a condition attached to the repudiation that they could later return and seek their legitim from the estate. The jurists denied any validity to this condition. ${ }^{59}$ Not satisfied with this result, the father then emancipated the son and entered into a compromissum, the resulting laudum handing to the son all right of the father in the estate in question. Alleging this laudum as his right, the son then gained judicial tenure (tenuta) to the property, but the uncle responded with sufficient proof to have the property returned. Then the son tried to have his uncle forced to compromise, by terms of a statute very similar to that of Florence. The uncle responded that the issue had to be resolved by a judge, that it was not compromisable in law. Floriano da San Pietro and Pietro d'Ancarano agreed with him. The issue of fact had been resolved. The issue now was one of law, and that was not something for compromise. ${ }^{60}$ To reopen the case was both illegal and, in view of the intent of the statute for rapid and peaceful settlements, inequitable. ${ }^{61}$

The following five rubrics also concerned arbitration, and only one of them had any overt grounding in the texts of 1355 . Rubric 67 forbade the Priors and Gonfaloniere di Giustizia to force anyone to compromise with them during their terms of office. Rubric 69 established that those not subject to Florentine jurisdiction could not hope to see their lauda judicially enforced unless they first paid their gabelle. ${ }^{62}$ Rubric 71 allowed exceptions and appeals from any laudum rendered by a magnate to the court of the Podestà.

The other two rubrics took great strides in generalizing the compromissum and laudum as legal situations. Rubric 68 , "De notificatione laudorum," set procedures by which the terms of a settlement were to be published. No laudum was valid unless formally published to both parties in their presence, or at least unless they had been hailed to hear the decision at a designated time and place. Ratification in the presence of the other party within thirty days was considered to constitute notification, as was notification by a crier of the Podestà or Capitano with the leaving of a note detailing the names of the parties, arbitrators, notary, and crier. ${ }^{63}$ With formal notification any time periods set in the laudum for payments or such began to run. Rubric 70, "De generali executione laudorum," reaffirmed that any validly contrivedand notified laudum received full legal protection "as if it were a guaranteed instrument," with no appeals, exceptions, or contradictions allowed (except for restitutio in integrum to a minor). Proof that obligations arising from a laudum had been settled was to be taken only in the form of public written instruments. The changes made evident in 1415 show that legal doctrines regarding arbitration, spurred it seems, by problems arising in practice, were still in the process of formation in the fifteenth century. 
For whatever reason - the greater procedural informality, the ultimate judicial sanctions - legal forms of arbitration seem to have flourished in Florence. Because the process began with a compromissum (a written agreement naming arbitrators, setting forth the issues, a time limit, and penalties for not complying) and ended with a laudum (a formal written publication of the terms of settlement) the popularity of the institution can be gauged from a survey of surviving notarial cartularies. This is not the place to attempt a full systematic survey. It is my strong impression, from pouring through dozens of these cartularies over the years, that arbitration was used frequently by many Florentines, more so in the fifteenth than the fourteenth century, to deal with an enormous variety of issues and relationships. Neighbours or partners might find it useful to resolve differences, for example. It was also extraordinarily useful in dealing with disputes among kin, notably in fraternal divisions of inheritance, in which case other kin, often affinal, were likely to be called upon as arbitrators. ${ }^{64}$ However, many compromissa and lauda indicate arbitrators not overtly related to either party and parties themselves linked only by a common interest, under conflict to be sure, with no explicit blood, marital, or neighbourly relationship. Business debts were a frequent matter for arbitration. By and large wealthier folk, those with substantial interests to transact, were overrepresented among compromising parties, as they were àmong those using numerous other private legal mechanisms in a city like Florence. but more modest folk, urban and rural, were also participants in arbitrations, against each other as well as against wealthy creditors or landlords. ${ }^{65}$ Also important is determining the motives of Florentines in arbitrations and their attitudes toward it. Lapo di Giovanni Niccolini undertook an arbitration as guardian for his young nephew "for the well being and peace and repose of the parties ... so it would not be necessary to litigate." ${ }^{66} \mathrm{His}$ comments reveal a distinguishing between arbitration and litigation that in terms of peace between the parties gave preference to the former. But how widely were his views shared?

The initiative in arbitration, as in vendetta, which retained a carefully circumscribed legality, ${ }^{67}$ lay with the parties themselves. The arbitrators in some cases had little to do but make a decision, and sometimes not even that. One finds lauda immediately following the compromissum in a notary's book, thus leading one to suspect that everything had been worked out in advance (on the parties' initiative or that of the arbitrators and/or other interested parties). They had simply gone to the notary to have it all written up in legal form (where there was often, as well, no existing form of contract or other transaction to cover what they had done). Occasionally private ricordi afford us a glimpse of such collusion. Lapo Niccolini, for instance, wrote in his of a compromissum lasting ten years, where the parties in fact had an agreement from the start on the payments eventually to be stipulated 
by the arbitrators. ${ }^{68} \mathrm{He}$ also noted a compromissum with his son Niccolaio, made for purposes of property division prior to arranging his marriage. "Thereafter [the arbitrators] did not issue any sentence, as the compromise expired [its term was two months], because we had not yet come to the completion of our intention." 69

The language employed in these documents tried to cover all contingencies. Arbitrators were almost always described as arbiter and arbitrator. They also tended simply to give the basic terms worked out by the arbitrator(s) with little justification or expansion into the relationship between the parties. The settlements themselves might be simply framed or they might contain a number of conditions and options giving either greater precision or greater flexibility to the relationship between the parties. One example, involving a prominent Florentine family, can be offered here.

November 23, 1428. Madalena, daughter of Carlo Strozzi and widow of messer Luchino Visconti of Milan, took the notary's son as her mundualdus and then moved to formulate a compromissum with her brother Piero acting in the name of her other brother Salamone. The chosen arbitrator was their prominent kinsman Palla di Nofri Strozzi. Salamone, duly informed of the compromissum made in his name, appeared that same day and personally ratified it. The following day Palla Strozzi pronounced sentence, having formally reviewed both parties' allegations. He found that Salamone owed Madalena 1000 florins (presumably for her dowry, but the origin of the debt is never specified). Because Salamone was short of cash, Madalena was given his house in Florence and Salamone had to guarantee fully her ownership. He had to make up the difference if the house were sold for less than 1000 florins, and, in the event of a sale, he had to cover damages on any outstanding rental leases. Salamone was not present at the reading of the laudum, but his wife, Ghita, daughter of the late jurist Filippo Corsini, was. She immediately renounced any hypothecary rights arising from her dowry over this house. Later that day Salamone formally ratified the laudum. ${ }^{70}$

It is impossible to tell from a laudum how real and intense was any conflict between the parties. Lauda were at times clearly treated as just another contract, noted in records with the same diffidence as a ny other legal transaction..$^{71}$ Where there was actual conflict, a laudum might only provoke further resentment. That was what happened in 1391 when Salamone di Carlo Strozzi's father-in-law, Filippo Corsini, served as arbitrator for his cousins. The dispute between Matteo di Niccol Corsini and Neri di Giovanni Corsini concerned their business ventures. Matteo complained that Neri had siphoned some 6500 florins out of the business between 1385 and 1389 . mainly by taking on accounts without informing him. Besieged by creditors, Matteo went to the Podestà and received a judgement for 5613 florins. Messer Filippo and other kinsmen pressured him to reach a compromise 
with Neri. Filippo as arbitrator then gave Matteo ownership of Neri's poderi in Nerzanoand Valifico, however, with a lifetime usufruct remaining with Neri. Matteo complained bitterly about this:

This false laudum, falsely given by the arbiters, and especially by messer Filippo, who wanted it thus and the others, that is Jacopo and Stefano Corsini, did not dare to contradict his malevolence and pronounced sentence in that mode along with him. ${ }^{72}$

Such coercion may or may not have been frequent, only much more systematic research can reveal that. But clearly it did happen. Nor was coercion the only reason there might be discontent. Even a fully agreed-to arbitration might later be deemed inadequate or insufferable. Bartolomeo di Tommaso Sassetti by arbitration gained a farm from his brother Federigo in 1436. "The said laudum was given as a precaution," he claimed, "because Federigo had many debts with the commune regarding his gravezze and because I might protect him and thus I did while I could and I assigned him an account on his things as appears in our old books." Years later, however, and despite reconfirmation in another laudum given in 1446, Federigo attempted to claim the farm, alleging that Bartolomeo had promised it to him. ${ }^{73}$ Fraud came into play in some arbitrations. One finds mention of a fictitious compromissum and laudum between Giovanni di Matteo Corsini and his sister in order to disguise ownership of a farm and protect it from creditors. ${ }^{74}$ Likewise Lapo Niccolini used arbitration with his sister to retrieve through her credits he had relinquished but on which he felt cheated. She promised verbally to deliver to him any money realized from pursuit of these claims, which promise she fulfilled. ${ }^{75} \mathrm{He}$ also several years later used arbitration to sell part of a podere to his brother Filippo in order to avoid the gabelle. ${ }^{76}$ At least once in the fifteenth century the governing councils of Florence saw the need to pass a law dealing with fraudulent use of arbitration settlements. And jurists would be called on to deal with such cases. In one such Antonio di Vanni Strozzi (1455-1523) defended a laudum between brothers from accusations of fraud that were based in part on the argument that the laudum's following immediately on the compromissum implied collusion. Strozzi, however, defended the work of an arbitrator from such a presumption; evidence would have to be produced and, in this case, documentary evidence seemed to substantiate that there was a debi claim to be settled. ${ }^{77}$ Such varied uses of arbitration threw up conceptual and practical problems for jurists.

One window into the problems of arbitration in Florence is the statue commentary of Alessandro Bencivenni (1385-1423) written in the early $1420 \mathrm{~s}^{78}$ The allegations prior to formal litis contestatio could set the terms for arbitration, as well as adjudication, ${ }^{79}$ so Bencivenni cautioned litigants 
to set out their cases clearly, to stick to true issues and not raise fictive ones (fol.49r). They could not seek a second laudum on the same matter, even if its resolution had come in court and not by way of arbitration (fol. 51v). However, if the nature of the case changed in any significant way (in the type of action or its cause, in the person of the plaintiff or defendant, or otherwise), then, on theauthority of Angelo degli Ubaldi (d. 1400), a compromissum could be sought even in the face of a previous laudum (fol. $51 \mathrm{v}$ ). The basic rule, however, according to Bencivenni, was that the compromissum was to be general in form, directing the arbitrators to look into any and every angle of the specific differences between the parties. The arbitration itself was to stick to issues of fact, it was not competent to deal with matters of law (fol. $51 \mathrm{v}$ ). In fact, except for what the statute directed regarding kin (by extension the high advisability of employing arbitration in dealing with valid or invalid wills [ $[$ lol.49v]), the rules of "common law" were to apply (fol. $52 \mathrm{r}$ ).

Bencivenni's gloss to "De notificatione laudorum" reveals that there were few major problems with this statute. He denied that minor omissions of detail, like the date of the compromissum, would invalidate a laudum, but he reaffirmed that sufficient notice of the arbitrators' findings be given to an absent party (fols. 52r-53r). Some parties would be more difficult to notify, that was all. The statute "De generali executione laudorum" also raised few problems, but it did pose the interesting issue of the date of effect of an arbitration, which Bencivenni concluded was the date of the compromissum ${ }^{80}$ Learned legal authorities disagreed on the question of the temporal term of the laudum, but the course actually taken in court had supported the procedural guarantee by which the creditor would move against the debtor's property without first having to establish the fact of the debt. The resolution lay in linking the laudum to the compromissum that necessarily preceded it.

Nello da San Gimignano ran into the problem more than once. In a consilium that survives in a sealed original in a Florentine manuscript, he confronted the following case. Two men, Piero and Paolo, had entered into a compromissum. Paolo pledged to have a monna Antonia ratify the agreement. She did not ratify the compromissum, she did ratify the laudum. Ratification of the laudum, however, occurred after the time limit on the compromissum had expired. Piero, therefore, argued that Paolo had failed to perform the condition set out in the compromissum and laid claim to the penalty for noncompliance. Nello took the case as sapiens at the behest of he court and found in favour of Paolo. It was absurd, he said, to claim that hough the laudum was framed within the requisite time and could be atified the compromissum, on the other hand, could not. Dionigi de' Barigiani of Perugia, who joined Nello on this case, concurred, adding the ogical observation that the force of the compromissum had not indeed :xpired but continued in the laudum. ${ }^{81}$ 
The parallels between the compromissum/laudum and the general procedure in formal civil litigation are striking, especially in the more widely used summary procedure. Recourse to an arbitrator was parallel in many ways to the recourse to a legal expert, doctor sapiens, from the midst of litigation..$^{82}$ Either the two parties agreed to put the case to a jurist, or the judge perceived the need for expert legal advice and, with the consent of both parties, approached a jurist with specific legal questions.$^{83}$ The jurist(s) had to be acceptable to both parties. The sapiens had to arrive at a fully valid legal result; he could not be as flexible asan arbitrator could in theory. ${ }^{84}$ Notification of the laudum paralleled the process of citation of a defendant to court to respond to a complaint. Above all, even in the courtroom much was dependent on the initiative of the parties - what issues to raise, how, when, and in what order ${ }^{85}$ The pleadings of the parties set the case in law, just as what they chose to lay before the arbitrator set the limits of his competence. The arbitrator himself could adopt a very formal procedure. ${ }^{86}$ The parallels are even more striking when we examine a case in full. Among the surviving Florentine consilia is one by Nello da San Gimignano and others concerning a laudum. Nello clearly was actively involved in such cases and had to confront conceptual issues revolving around arbitration as practised by Florentines. And the passage from arbitration to the context of formal litigation, in which we find Nello's text, is itself revealing of how interconnected the two procedures were.

\section{The Consilium of Nello da San Gimignano}

The facts of the case were these: Monna Antonia wrote a testament in which she left to a Giovanni di messer Simone her houses and furnishings located in Florence. She also named him and his brother Francesco as her universal heirs. These two had three nephews, Simone, Berto, and Marco, sons of their deceased brother Antonio, who were not named in monna Antonia's testament.

And said Francesco and Giovanni, wanting to make adequate provision for their nephews in the estate of the said Antonia, made among themselves a private document and agreement in which it is established that all possessions, things, money, credits and debts that are acquired and found in the estate of said monna Antonia belong to Giovanni for a third part and to Francesco for another third and to Simone and his brothers for the other third, not withstanding the testament and bequest $\ldots . .^{87}$

Later, however, disagreement arose and a compromissum was arranged with two men (unnamed) chosen as arbitrators. These "arbitri et arbitratores" affirmed that the private written agreement dividing Antonia's estate into three equal parts was indeed valid and should be executed "ac si 
esset instrumentum guarentigiatum." These arbitrators later reversed themselves, however, annulling the first laudum and issuing a second. They had since learned that the three nephews had been under the guardianship (tutela) of their uncles and had grievances about the tutorial management of their affairs. So the arbitrators ordered the uncles to turn their thirds over to the nephews. Any amount remaining after settling this debt would then be split into thirds.

The nephews went to court to get this second laudum enforced. The uncles (or their legal representative) countered that the arbitrators had not had that issue committed to them. They had been told to deal with Antonia's estate and not with thetutela. There was a defectum potestatis on this matter. The nephews' response (or, again, that of their representative) was that the laudum was valid because the language of the compromissum not only pointed to a specific issue but to a general state of controversy and the need to resolve it. The dispute and its resolution were separate.

There were many questions to which the historian cannot find an answer. We do not know what the families were, for no surnames were given. The relationship between Antonia and these men is never specified. The value of her estate and the amount in question from the tutela a re not revealed. The identity of the arbitrators and their relationship to the parties is a nother bit of information that is lacking. These matters did not have a bearing on the legal status of the case, so they were not transmitted to the sapiens. It is also not certain what court handled the case, though presumably it was that of the Podestà, nor on whose initiative the case went to the sapiens - the judge's or the parties' ${ }^{88}$ But what is clear is that, upon whatever initiative, the parties had to agree and that they had to set the legal issue for the jurist as a result of their arguments.

Nello di Giuliano Martini Cetti da San Gimignano was an excellent choice. He was a prominent figure in the ruling councils and elite circles of Florence. He was also a highly esteemed jurist, a writer of incisive legal treatises, frequently called upon to render consilia in cases that arose in the various courts and political bodies of Florence..$^{89}$ According to Lau ro Martines, Nello held a high opinion of city government in Florence, as sibi princeps, and of the grounding of statutes in the public utility. ${ }^{90}$ In 1427 he would actively advocate adoption of the sweeping fiscal reform of the catasto as an appropriate measure of public utility. ${ }^{91}$

Nello began his consilium by noting that the contentiousness of the litigants and the complex issues required learned intervention:

If everyone would be easily pleased with the truth for a decision on this case there would be little to do, but because such matters rarely transpire without extended treatment of the question, it is necessary to reach the truth of the article not with a few words but by a full examination. ${ }^{92}$ 
In this case a "full examination" meant a formal pro-et-contra presentation.

First he rehearsed the arguments in favour of the validity of the laudum. It had been rendered in the form prescribed by "common" and municipal law. All the affairs between the parties had been committed to the arbitrators "as if special mention had been made of them, the force of which general clause silences anyone trying to have the laudum negated." ${ }^{93}$ Support for these arguments came from the Digest, as did the corroboration for the next point - that by statute the laudum was an instrumentum guarentigiatum, a point also made by Bartolo da Sassoferrato (d. 1357) ${ }^{94}$ By statute one could not oppose execution of such an instrument, for the intent of the guarantee was to allow thecreditor to realize his money without having to prove the existence of the debt first. Furthermore, additional legislation (to be incorporated in the statutes of 1415 as "De generali executione laudorum") seemed to preclude any procedure for nullifying a laudum by a discontented party. Even if the arbitrators had exceeded their authority by considering the tutelary obligations, it had been in their competence to dispose of Antonia's estate and that part of the laudum should stand. Here the added authority of Bartolo was again invoked. In his commentary on the lex Quid tamen § Intra of the title De receptis: qui arbitrium receperint (commonly designated simply De arbitris in medieval law) (D. 4.8.21,12), Bartolo provided an example of discretion of an arbitrator. The civil law text concerned whether an agreed penalty could be exacted from a party who failed to act by the specified day as ordered by an arbitrator. Bartolo had determined that an arbitrator could exact a penalty only if the compromissum said so, but he could set a time limit and reduce the penalty. ${ }^{95}$ The point in the present case being that the treatment of the estate and of the tutela had to be seen as separate. On this basis the laudum in favour of the three nephews had to stand.

The issues raised in the case thus touched on an area where the legal landscape was still in formation in the early fifteenth century - the problem of appeal of a laudum given ex necessitate statuti in a dispute between kin. The reductio ad arbitrium boni viri did not provide for the correction of errors in the laudum..${ }^{96} \mathrm{Ju}$ risprudence, as opposed to statutory law, was very concerned "with the possible harm caused by an arbitral decision based on equity not conditioned or limited by the compromissum - in this case the laudum would not have been an expression of the parties' autonomy but the direct result of an act of judgment exclusively bound to the arbitrator's will." ${ }^{97}$ Doctrinal statements, formulated now in the courtroom more than in the classroom, tended to line up on the side of appellability. No less a figure than Paolo di Castro, who a few years later would be involved in revising Florence's statutes, stated in a consilium that a bad laudum had to be reworked, no matter what the statutes seemed to say. ${ }^{98}$ So perhaps it is 
not surprising that, in Nello's case. it was the contrary position - that the laudum was not valid - that carried the day.

In the first place. and most importantly, the arbitrators had exceeded the powers vested in them by the parties: "the powers of the arbiters or arbitrators depend on the compromissum such that those arbitrating beyond the compromissum do nothing, rather the arbitration is null by defect of power or investigation." ${ }^{99}$ Clear legal support for this position lay in three texts of the Digest cited by Nello, especially the lex Diligenter (D. 17.1.5), which required that one acting by authority of a mandatum remain within its terms, and by the lex Non distinguemus $\S$ De officio (D. 4.8.32,15), which directly required an arbitrator to address only the issue set forth for him in the compromissum. In the case before him, said Nello, the arbitrators had been asked to deal with Antonia's estate, not with the tutela. Their actions could not be justified (and the laudum validated) on the grounds that they were merely setting a condition to the settlement of Antonia's estate, for what was notentrusted to their disposition could not be treated conditionally. The arbitrators also could not order a second laudum. No less an authority than Baldo degli Ubaldi had taught that "it is certain that an arbiter cannot command a second compromise in him, unless it be by an act of the parties deferring to him." 100 The arbitrators had acted in fraudem by breaking the rules enjoining them to remain within the terms of the compromissum. The only reason Nello could find for their decision to favour the three nephews in the division of Antonia s estate was to generate fear in Francesco and Giovanni so that they would make restitution for the tutela. ${ }^{101}$

It would be a dangerous principle to allow arbitrators to do what they were not directly permitted. The problem was to demonstrate just what was allowed to arbitrators by the language of the notarially encoded compromissum. The standard formula stating that arbitrators were to look into "omni et toto eo" causing controversy between the parties did not expand their competence beyond what had been expressly mentioned. In actuality, however, many compromissa did not state a specific issue, so Nello was effectively leaving the competence of the arbitrators to a verbal understanding reached before drawing up the compromissum and not necessarily specifically embodied in it.

That general clause ["de omni et toto eo"] is restricted by what is specified so that it may not be extended to thoroughly different and separate matters, as is set forth in the lex Sed et siquis § quesitum, ff. si quis cautionibus (D. $2.11 .4,4$ ), in lex Emptor $\S$ lutius, ff. de pactis (D. 2.14.47,1). If we should say otherwise it would be purposeless to specify any matter in a compromissum if, not withstanding that expression, that clause that "of all and everything etc." be understood as general for all matters; but because by that expression the compromissum is called special, not general, it would appear that 
that expression of specifics operates not withstanding that clause. So that clause then makes a compromissum full and special, but it does not make it general. It is the case if one rightly considers lex Si cum dies § plenum.ff. de arbitris (D. 4.8.21,5.6). ${ }^{102}$

By thus resting the argument on the compromissum, Nello did not have to confront the problem of whether these arbitrators had acted as arbitri or arbitratores, for in either case their competence was still set by the compromissum.

Circumstances also restricted the scope of the compromissum according to texts of both civil and canon law. In addition the clause "de omni et toto eo" could not license proceeding beyond the terms of the compromissum anymore than an illicit agreement not to oppose anything resolved extra compromissum. Here Nello could cite in support the commentary of Guillaume de Cunh to D. 15.1.3,8, Baldo to the Peace of Constance, and consilia of the Florentine jurist Francesco Albergotti d'Arezzo (1304-1376). Baldo certainly provided crucial support here. In no uncertain terms with reference to canon law, he denied validity to any sententia that went beyond the compromissum..$^{103}$ It is also interesting thatNello dealt with the phrase "de omni et toto eo," which could be read, as he read it, more or less in the singular. Many compromissa also declared that the arbiter was commissioned "generaliter" to look into "omnes lites, causas, et questiones" that had arisen between the parties. That there was a plurality of disputes would admit a greater possibility of allowing what the arbitrators had done in this case in order to achieve a lasting and peaceful settlement between the parties. That Nello did not see a plu rality of disputes, however, seems to have been fully consistent with prevailing ju risprudential practice. Angelo degli Ubaldi had on several occasions confirmed in consilia that arbitrators were limited to the issues set forth in compromissa and that general language did not give them license to inquire broadly into all facets of the relationship between parties. ${ }^{104}$ Angelo had further argued in at least one case that a laudum iniquum could be appealed to the arbitrium boni viri even if a clause renouncing appeals had been included in the compromissum. ${ }^{105}$ Clearly, despite the principle of inappellability of arbitration, the arbitrators were not given a blank check.

A second line of argument against the second laudum was that the statute concerning instrumenta guarentigiata did not preclude recourse to an exceptio nullitatis against a laudum. Here Bartolo in both his consilia and his commentary in D. 29.1.24 provided corroboration. ${ }^{106}$ The Florentine statute forbidding that one seek nullification of a laudum also did not apply in this case: "it is especially true because, as appears in the beginning of the legislation, it requires the laudum be given ex compromisso, so it is clear that it does not prevent [seeking nullification in this case]." 107 By a 
more complex process of reasoning Nello further concluded that one could not divide the laudum into two clauses, one dispositive and the other conditional, and permit the latter to stand. What could not be done dispositively could not be done conditionally with regard to iuris effectum. Here he found support in Baldo and Bartolo. ${ }^{108}$ "Nor does it matter that there are two sections, because they are connected and one depends on the other." 109 Bartolo himself had concluded in a consilium that "when an arbitration is invalid in one part it is invalid in total." 110

Finally Nello had to interpret a passage from Bartolo's commentaries that seemed to support the laudum. In examining the lex Quid tamen (D. $4.8 .21,12),{ }^{111}$ Bartolo had allowed that "if there are different sections [in the compromissum], they can be separately pronounced upon, unless it is enacted otherwise." An arbiter or arbitrator could resolve all issues at once, or do some at one time and the rest later, however he pleased, said Bartolo. Nello insisted that that did not mean Bartolo approved of the laudum but that if he seemed to it was because in his commentary the arbitrator did not act in an area where he could not. And one need not conjecture on what was in the arbitrator's mind in this case, said Nello, for he clearly had arbitrated on what had not been committed to him. ${ }^{112}$ Interestingly, though he hinted that Bartolo was not as pliant on this point as it might seem at first glance, Nello did not fully explicate the Bartolist text. At the end of his commentary on Quid tamen Bartolo directly said that an arbitrator could correct his judgment only if the compromissumexpressly allowed it. The principle behind this position was the same one that Nello had embraced in framing his opinion: "For an arbitrator does not have this power by common law... But I think it can be attributed to him by the consent of the parties."113

Nello subscribed his opinion on 12 December 1411. It passed then to the hands of Filippo di messer Tommaso Corsini (13341421) - the same man whose arbitration provoked the ire of his kinsman seen above. Corsini found nothing to dissent from and nothing to add. He had reached the same conclusion in a similar case, as had his colleagues on that occasion, Pietro d'Ancarano (1330-1416), Onofrio and Marco da Perugia. The next day Roggeri d'Antignalla (fl. 1390s) reviewed the case and added some arguments to Nello's. He was especially concerned that legislation denying all recourse against an arbitration seemed harsh. To temper this he pointed to the principle that no sin could be allowed by law. "Therefore such general terms contained in the statute must be taken reasonably so that nothing is done against the intent of the statute, otherwise fraud may be done to the law, that is, to that statute." 114 So it could not be maintained that one could not proceed against a laudum emitted beyond the arbitrator's authority. Antignalla's argument, however, seems weak. There was no real question of fraud or dolus in this case. There were no doubts about the arbitrators' intentions. In question was wheter they had exceeded the 
licit bounds of authority given them by the parties - a separable issue. Antignalla was effectively only explaining one reason why in general arbitrators should be held to such limits.

It was two weeks later that a fourth jurist, Rosso d'Andreozzo degl'Orlandi (fl. 1400-1420s) penned his signature on the document. He added no further arguments or citations. Why at that comparatively late date his corroboration was seen as necessary or desirable one cannot say. What one can say is that the jurists, most especially Nello, had constructed a careful opinion that reaffirmed the voluntary nature of the laudum and compromissum while overturning a laudum in the name of legal principle. absolute and not voluntary.

\section{Conclusions}

Decisions like Nello's helped solidify the place of arbitration in the regularly functioning legal institutions of Florence. He helped to define the procedures and competence of arbitrators and thus the entire connection between arbitration and other processes. At the same time it was conceded that arbitrators had effective power within the limits set for them by the parties and even had latitude in how they chose to exercise their powers. As Angelo degli Ubaldi had put it in overturning a laudum where the arbitrator had been compelled to find in a certain fashion, "the nature of arbiting [arbitrium] is this, that the faculty of arbiting is free to make the judgment it wants." 115

Nello's consilium did not resolve the dispute between the two uncles and their three nephews. All it did was overturn the second laudum. Where the matter went from there was up to thelitigants. Division of monna Antonia s estate was probably resubmitted to arbitration. The grievances over the uncles' administration of the tutela was another issue. The nephews could let it drop, negotiate it directly with their uncles, submit it to arbitration, or formally litigate, depending on their desires, the strength of their case, and the determination of the opposition.

Unless the uncles conceded that there had been maladministration, the nephews would probably have to go to court to establish their right to restitutio in integrum. Where the existence or nature of a right was in question or where the nature of a relationship or personal status was open to doubt, litigation provided the best forum. Arbitration was best suited to issues of property, where facts or amounts were at issue, or to instances where relationships or status had been posed in terms of property. ${ }^{116}$ In the arbitration's original form there seemed no question of right to the estate, the specifics of division were all that mattered. The nephews treated the matter of monna Antonia's estate as a property issue, as did the arbitrators. But the normative basis of the claim shifted between the first and second 
laudum - from the uncles' grant to their tutorial administration. In the process the relationship between the parties was also thrown open, as ward/ guardian overlaid nephew/uncle. The relationships were partly defined by and made operable in rights over property.

Thus the nature of the dispute, its form and precise object, was not fixed. It varied by procedural context; given one form in the first laudum, it became something else the second time around. In court it was further redefined; now they were parties to an arbitration and the matter in dispute was the validity of the settlement, contested on the grounds of the competence of the arbitrators.

Arbitration had been designed to avoid litigation. At least it was broadly understood as a means to bring peace between the parties. But in this case, as in others, it had clearly failed to do so. ${ }^{117}$ Rather than defusing animosities it had exacerbated them. Unilateral reformulation of the matter by the arbitrators was the problem. If arbitration was to succeed it had to be accepted by both parties. But why should the uncles (short of occupying a politically weak and untenable position) accept a laudum that left them with far less than they anticipated - and that on the basis of something not submitted by them to the arbitrators? Their litigious protest makes sense (perhaps especially if their division with the nephews was intended by them to make up for any shortcomings in the administration of their estate). So too does the attempt of the nephews to change the nature of the claim - that is, perhaps they were worried that by accepting the division in the first laudum they were relinquishing their right to claims arising from the tutela, and shortchanging themselves in the process. Why the arbitrators did this - other than, perhaps, from a sense of fairness - is hard to say.

Where the arbitration failed to make peace, the formal machinery of the law could step in - but not without regard to the arbitration. Here lies the legal a mbiguity highlighted by our investigation. How did supposedly informal arbitration fit into formal law? In one sense by producing a transaction, a contract,whose enforcement was actionable in the courts. But also by being beyond appeal. Contracts could be judicially invalidated for a number of reasons, to be sure, and lauda too could be contested and in that sense, if not in a strict sense, appealed. A laudum, however, had to be contested on a point of law. ${ }^{118}$ If right was conceded, the laudum could not be contested on an issue of fact. There it could indeed be "arbitrary." Its essential "rightness" was not then in question. Where it was, the law proposed remedies. These formally presented remedies, especially in contrast to the greater informality of arbitration, could render the issues of right "true" and "unquestionable" and downplay any uncertainty in the law. ${ }^{119}$ Yet such uncertainty existed. In the case we have considered, and in others, the problem lay in the factual and situational specificity of arbitration, on 
the one hand, and the (notarially enshrined) general charge to the arbitrator(s) to inquire broadly into the causes of dispute between the parties and do whatever it took to bring them peace, on the other. Nello, however, found it necessary to restrict arbitrators to a very narrow sense of the issue at least to make clear that they could not unilaterally change the nature of the rights to which they were theoretically providing equitable redress. Uncertainty also existed on the problem of appeals. Martone has argued, based on a reading of Luigi Lombardi's work on forensic jurisprudence, that ju rists were only responding to clients' interests in permitting appeals of lauda. ${ }^{120}$ However, for every party seeking to overturn a laudum, there was also one seeking to uphold it. While allowing litigation on these points may have played into the hands and pockets of practising jurists, they were also offering "logical" solutions (versus conceptual exegesis) that fit their sense of justice. In the last analysis, their allegiance was to the just legal order of society; and the best guarantee of that was the law in all its formality and texts. So lauda could not be appealed, and they could. So equity stood in contrast to legality, and it was subsumed within the latter.

Jurists like Nello and the others who have been mentioned were professionally wedded to notions of justice and right (ius and iustitia). Their training suited them for such contested and doubtful issues of law as emerge in formal litigation. They may have been as happy to leave legally insignificant issues of "fact" to arbitration. But in so doing they were also according enforceable standing to findings whose justice was open to doubt. On the other hand, the jurists also embraced notions of equity and the goal of social peace and order fostered by arbitration.121 Jurists were also familiar with arbitration at first hand. They served as arbitrators for kin and friends. They had problems of their own arbitrated. As members of the property owning elite themselves they could see the utility of arbitration's speedy and informal procedure. What we see taking shape in the opinions before us is an interesting intermediary procedure. By holding down the scope of the arbitration to the issue(s) assembled by the parties, while giving the arbitrator power to inquire into all aspects of the parties' relationship and actions touching on the issue(s), the jurists were placing it midway between the formal and abstract, designed "to reduce the infinite variety of individual conflict casesto standard uniform units so that they may be handled with dispatch and with demonstrable fairness" and the informal that "attempt to deal with the total relationships and total social personalities of the parties, thereby admitting the unique nature of every case." 122 The "equity" arrived at in every case could thus be grounded in "right" and mask any fundamental inequities between the parties. The outcome of arbitration need not be any fairer; a party with an advantage could still use it. ${ }^{123}$ But the ideology of fairness in the arbitration would survive, especially as the courts posed as the guarantors of it. 
With the enhancement of enforcement and validation by the formal law of courts and jurists, arbitration grew as a thriving legal institution in Florence and elsewhere. As "facts" were resolved in arbitration, people could become more aware of the rights defining them, especially as lauda clothed them in proper notarial legal language, so that their sources and terms could become apparent. Here too arbitration was an intermediate form - not as rule-centred as litigation but not as fact-oriented as more informal mechanisms. Rules were always implicit, even if not explicitly abstracted from events (any more than the arbiter was usually fully abstracted from prior ties to the parties). They could be made explicit in contesting a laudum. Rules and facts are never fully separate in disputes. ${ }^{124}$ Exchange of claims and allegations can reveal what the rules are, what facts are important, and what are not.

Arbitration, finally, may have played an important role in the growth of law and the decline, never linear, of violent self-help. The effectiveness of legal procedures in medieval Europe "was dependent less on the coercive powers of officials, than on the preparedness of parties to accept the procedures of the court, and on their willingness to accept court judgements or to come to terms informally." 125 The more frequently people resorted to arbitration the more familiar and comfortable they would be with the law and the more they might escalate their legal tactics to the field of formal litigation, and the more likely would be their success there. ${ }^{126}$ Nor is or was it true that norms invoked in arbitration were always general and imprecise, in contrast to the precise rules at play in litigation. ${ }^{127}$ The object in dispute and the normative language to encapsulate it were both negotiated as a dispute moved along. ${ }^{128}$ We have seen examples. The matters in arbitration were fairly precise. ${ }^{129}$ Rights and interests could be clearly identified, including interests of others who might bring pressure to keep the parties to the peace. Even where they did not succeed - and in the last analysis, terminating the dispute lay with the parties, as did framing it in the first place - and did not reestablish social relationships, they could bring some sort of closure to the immediate issue and provide time, a delay, during which a real settlement might be arranged. ${ }^{130}$ In sum, arbitration was not onedimensional, especially not in its crucial intermediary position as a form of dispute processing appended to the legal system of a city like Florence.

\section{Clemson University}

Notes

1 Francesco Calasso, Medievo del diritto, vol. 1: Le Fonti (Milan 1954); Manlio Bellomo, Società e istituzioni in Italia dal Medioevo agli inizi dell età moderna (Catania 1982) Arthus Engelman et al., A History of Continental civil Procedure, trans. and ed. Robert Wyness Millar (Boston 1927 reprint ed., New York 1969); and Pietro Sella, Il procedimento civile nella legislazione statutaria italiana (Milan 1927). 


\section{2 / Renaissance and Reformation}

2 John Larner, Italy in the Age of Dante and Petrarch, 1216-1380 (New York, 1980), pp. 102-104, 110-111, 123-124; Lauro Martines, Power and Imagination: City-States in Renaissance Italy (New York, 1979); Robert Davidsohn, Storia di Firenze, vol. 4: I primordi della civiltà fiorentina, Part 1, trans. from German Eugenio Dupré-Theseider (Florence, 1973).

3 Edward Powell, "Arbitration and the Law in England in the Late Middle Ages," Transactions of the Royal Historical Society, 5th ser., 33 (1983), 55. In addition, see Frederic L. Cheyette, “"Suum cuique tribuere," "French Historical Studies 6 (1970), 287-299; Stephen D. White, " 'Pactum ... Legem Vincit et Amor Judicium': The Settlement of Disputes by Compromise in Eleventh-Century Western France," American Journal of Legal History 22 (1978), 281308; Jenny Wormald, "Bloodfeud, Kindred and Government in Early Modern Scotland," Past and Present 87 (1980), 54-97; J.A. Sharpe, “'Such Disagreement betwyx Neighbours': Litigation and Human Relations in Early Modern England," in Dispute and Settlements: Law and Human Relations in the West, ed. John Bossy (Cambridge 1983), 167-187; and Michael Clanchy, "Law and Love in the Middle Ages," in Disputes and Settlements, 47-67; William Ian Miller, "Avoiding Legal Judgment: The Submission of Disputes to Arbitration in Medieval Iceland," American Journal of Legal History 28 (1984), 95-134.

4 Powell, pp.53-54; Karl S. Bader, “' 'Arbiter, arbitrator seu amicabilis compositor,' " Zeitschrift der Savigny-Stiftung für Rechtsgeschichte 77 (Kan. Abt.) (1960), 239-276.

5 Luciano Martone, Arbiter-Arbitrator: Forme di giustizia privata nell 'età del diritto commune (Naples, 1984), an excellent comprehensive and, at times, provocative examination of legal doctrines, statutes, and notarial practices, though not of litigation or even of actual arbitrations.

6 Powell, pp.50-51, and his "Settlement of disputes by Arbitration in Fifteenth-Century England," Law and History Review 2(1984), 38-41; Nicole Castan,"The Arbitration of Disputes under the Ancien Regime," in Disputes and Settlements, pp.219-260; Richard L. Kagan, Lawsuits and Litigants in Castile, 1500-1700 (Chapel Hill 1981), pp.82-84.

7 One area of law producing pertinent examples was usury; cf. R.H. Helmholz, "Usury and the Medieval English Church Courts," Speculum 61 (1986), 377, and see his "Ethical Standards for Advocates and Proctors in Theory and Practice," Proceedings of the Fourth International Congress of Medieval Canon Law, Toronto, 2125 August 1972, ed. Stephan Kuttner, Monumenta Iuris Canonici, Series C: Subsidia, vol. 5 (Vatican City, 1976), pp.291-293.

8 Sally F. Moore, "Law and Anthropology," Biennial Review of Anthropology (1969), 252-300; J.F. Collier, "Legal Processes," Annual Review of Anthropology 4 (1975), 121-144; Francis G. Snyder, "Anthropology, Dispute Processes and Law: A Critical Introduction," British Journal of Law and Society 8 (1981), 141-180.

9 And even in modern societies there are relationships that cannot risk frequent handling by legal authorities. Cf. KlausFriedrich Koch, Soraya Altorki, Andrew Arno, and Letitia Hickson, "Ritual Reconciliation and the Obviation of Grievances: A Comparative Study in the Ethnography of Law," Ethnology 16 (1977), 169-183.

10 For what follows, see Vilhelm Aubert, "Law as a Way of Resolving Conflicts: The Case of a Small Industrialized Society," in Law in Culture and Society, ed. Laura Nader (Chicago, 1969), 282303; P.H. Gulliver, Disputes and Negotiations: A Cross-Cultural Perspective (New York, 1979); and various studies by Richard L. Abel, "The Rise of Capitalism and the Transformation of Disputing: From Confrontation over Honor to Competition for Property," UCLA Law Review 27 (1979-80), 223-255; "Theories of Litigation in Society: 'Modern' Dispute Institutions in 'Tribal' Society and 'Tribal' Dispute Institutions in 'Modern' Society as Alternative Legal Forms," Jahrbuch fur Rechtssoziologie und Techtstheorie 6(1979), 165-191; and "A Comparative Theory of Dispute Institutions in Society," Law and Society Review 8 (1973-74): 217-347. A typology in terms of modes of production is offered by Katherine S. Newman, Law and Economic Organization: A Comparative Study of Preindustrial Societies (Cambridge, 1983). And generally Sally Falk Moore, Law as Process: An Anthropological Approach (London, 1978). It should be acknowledged that some of the interest shown in methods of dispute settlement other than adjudication is undertaken with practical considerations in mind - finding ways to alleviate the crush on courts and improve the legal system. This concern appears in some of Abel's work and also in the volume Accessto Justice, vol. 4: The Anthropological Perspective: Patterns 
of Conflict Management: Essays in the Ethnography of Law, ed. Klaus-Friedrich Koch (Milan, 1979), and the special issue on "Dispute Processing and Civil Litigation" of Law and Society Review 15 (1980-81).

11 Powell, "Settlement," p. 24.

12 Ibid., pp. 35-36.

13 White, 308; Powel, "Arbitration," 55-56; Kagan, 17-18; Chris Wickham, "Comprendere il quotidiano: Antropologia sociale e storia sociale," Quaderni storici 60 (1985), 839-857; Janet L. Nelson, "Dispute Settlement in Carolingian West Francia," in The Settlement of Disputes in Early Medieval Europe, ed. Wendy Davies and Paul Fouracre (Cambridge 1986),pp.45-64, who sees property issues as more suited for court processing, matters of relationship or honour more apt for feud or arbitration.

$14 \mathrm{Cf}$. White, Clanchy.

15 On this theme, see the recent volume The Settlement of Disputes in Early Medieval Europe (note 13 above), especially the contributions of Chris Wickham, "Land Disputes and Their Social Framework in Lombard Carolingian Italy, 700-900," pp.105-124, andJenny Wormald, "An Early Modern Postscript: The Sandlaw Dispute, 1546," pp.191-205.

16 Simon Roberts, "The Study of Disputes: Anthropological Perspectives," in Disputes and Settlements, pp.1-24, at 17.

17 "Conclusion," in Settlement of Disputes in Early Medieval Europe, p.239.

18 Powell, "Settlement," p.34.

19 Martone, p.10-17.

20 Roberts, p. 12-15, categorizes dispute processes ranging from negotiation to adjudication, but also cautions against rigid ethnocentric divisions.

21 Roberts, p.14; cf. also Miller, p.101.

22 Cf. Powell, “Arbitration," p.60; and generally Carol J. Greenhouse, "Mediation: A Comparative Approach," Man, n.s. 20 (1985), pp.90-114.

23 For now see Powell, "Arbitration," pp.56-58; Miller, p.98.

24 Powell, "Arbitration," p.62; also see Kagan, p.245; Miller, p.97, notes that feud was also an alternative sanction to arbitration.

25 "Conclusion," in Settlement of Disputes in Early Medieval Europe, pp.234, 239.

26 Martone, esp.pp.161-168, mounts an effective argument that it was precisely the admission of appeal to court of an inequitable laudum that solidified the place of arbitration in the legal order of Italian cities.

27 Powell, "Arbitration," p.66, for one, implies that on the continent arbitration and law may have enjoyed a more fluid interaction.

28 The arbiter was thus dialectically assimilated to the iudex and followed an almost judicial procedure. The difference between the arbiter and the iudex was essentially that the former was chosen by the parties, at whatever stage in their dispute or litigation, whereas the latter held a jurisdiction giving him cognizance of the dispute without regard to the parties. Cf. Linda Fowler, "Forms of Arbitration," in Proceedings of the Fourth International Congress of Medieval Canon Law, pp.133-147; Antonio Padoa Schioppa, Ricerche sull'appello nel diritto intermedio, vol. 2: I glossatori civilisti (Milan 1670), pp.37, 80-88; Martone, pp.29-34.

29 Durante, Speculum iudiciale (Venice 1566), Book I, Part I, 155 (see note 38, below).

30 Martone, pp.74-79, 88-92.

31 Sella, p.206.

32 Tractatus de arbitris, in Opera omnia (Venice 1602), vol. 10, fol. 146va.

33 Generally, see Martone, pp.36-56.

34 Fowler, pp.139-140; Padoa Schioppa, 2:85-88.

35 In the metaphor of the thirteenth-century glossator Azzo, "cum arbitri sententia non liget plus quod aliquod filum tenuissimum ligaret hominem" (quoted in Padoa Schioppa, 8283). 


\section{4 / Renaissance and Reformation}

36 Obviously there were, in fact, all sorts of consequences for others when their debtors' or creditors' property, for example, was allocated by arbitration. But this was no more nor less so than would have been the case from other private transactions (e.g. sale).

37 Ibid., pp.85-87; Martone, pp.58-60.

38 Durante, Speculum iudiciale, pp.154-155: "nam arbiter est quem partes eligunt ad cognoscendum de questione, vel lite: et sic sumitur super re litigiosa et incerta, ut ea cognoscatur: et debet iuris ordinem servare. Et sit semper cum poenae stipulatione. Non cogendum et statur eius sententia, aequa sit, sive iniqua. $\mathrm{Nec}$ ab eo appellatur. $\mathrm{Nec}$ ad arbitrium viri reducitur secundum quosdam. Arbitrator vero est amicabilis compositor. Nec sumitur super re litigiosa, vel ut cognoscat: sed ut pacificet, et quod certum est dividat: ut in societate, quam certum fuisse contractam. Sed eligitur, ut det cuilibet certam suam partem, quae ipsum ex societate contingit. Et hoc non dicitur arbitrium. Nec tenetur iuris ordinem observare; nec statur eius sententiae, si sit iniqua: sed reducitur ad arbitrium boni viri."

39 Bader, pp.272-273; Sella, p.206; Fowler, pp.134-136.

40 On equity in this context, see Martone, pp.111-119.

41 Ibid., pp.162-163.

42 Ibid., p.127. In Baldo's terms, to C. 2.55(56).1 (Venice 1577), fol. 104rb: 'Tbi loquitur in arbitratore si inique laudat, reducitur ad bonum virum. Secus in arbitro. Ratio haec est: quia arbiter assumitur ut sit finis litium. Et ideo etiam modica laesio tollatur. Sed arbitrator non assumitur ut sit finis litium: quia ut plurimus assumitur super contractibus. Et posito quod assumatur super lite: non videtur ei permissum nisi ut parum ledat." Baldo's sense of the matter certainly does not square with that of the legal anthropologists who would not see any such distinction.

43 Bader, pp.275-276; Karl-Hans Ziegler, "Arbiter, arbitrator und amicabilis compositor," Zeitschrift der Savigny-Stiftung für Rechtsgeschichte, (Rom. Abt.) 84 (1967), 376-381.

44 Sella, pp.206-208. The difference between arbitrium and compromissum lay in the fact that the latter carried stipulated penalties for a party's failure to follow through.

45 Fowler, pp.143-145.

46 Martone, p. 94 n. 62.

47 Ibid., pp.133-144.

48 Sella, pp.207-208.

49 The most eloquent evocation of the ethos of Renaissance families is Francis William Kent, Household and Lineage in Renaissance Florence: The Family Life of the Capponi, Ginori, and Rucellái (Princeton 1977); see also Jacques Heers, Family Clans in the Middle Ages, trans. Barry Herbert (Amsterdam 1977); and Gene A. Brucker, Renaissance Florence, rev. ed. (Berkeley 1983), chap. 3. On familial conflict see my "Honor and Conflict in a FifteenthCentury Florentine Family," Ricerche storiche 10 (1980); 287-310.

50 This touches on a theme in histories of political thought. For now, in relation to legislation, litigation, and humanist rhetoric, see Julius Kirshner and Anthony Molho, "The Dowry Fund and the Marriage Market in Early Quattrocento Florence," Jourmal of Modern History 50 (1978), 435-436; Francesca Klein, "Considerazioni sull'ideologia della cittå di Firenze tra Trecento e Quattrocento," Ricerche storiche 10 (1980), 311-336; and my "'As If Conceived within a Legitimate Marriage': A Dispute Concerning Legitimation in Quattrocento Florence," American Journal of Legal History 29 (1985), 298-300.

51 A[rchivio di] S[tato di] F[irenze], Statuti del comune 16(Statuti del Podestà del 1355), fols. 81r82r. Also cf. Statuti della repubblica fiorentina, ed. Romolo Caggese, vol. 2: Statuto del Podestd̀ dell'anno 1325 (Florence 1921), pp.168-169.

52 The terms used by the statute are securitas and satisdatio. Satisdatio reinforced a basic promise to pay damages and so forth by giving surety (cf. Max Kaser, Roman Private Law, 2nd ed., trans. Rolf Dannenbring [Durban 1968], p.40).

53 Ibid., fol. $81 \mathrm{v}$ : "Et possint dicti arbitri etiam eligere tertium predictum infra dictum tempus si discordes essent, qui tertius per inde habeatur et sit ac si in compromisso facto in eosdem arbitros esset expresse." 
54 Martone, p.159.

55 Ibid., p.159.

56 Martone, pp.162-163.

57 Statuta communis Florentiae anno salutis mccccxv, 3 vols. (Freiburg [Florence] 1778-83), 1: 162164.

58 Also added was the curious provision that no one having six children could be forced to accept a compromise. Both 1355 and 1415 contained a clause to the effect that no popularis could be made to act as arbitrator for magnates, even if he were related.

59 B[iblioteca] N[azionale di] F[irenze], Landau-Finaly 98, fols. 171r-175r. Bartolomeo da Saliceto (d. 1412) also had a hand in this first consilium.

60 Ibid., fols. 176r-v: "quod rego a modo fiendum restat, concernit solum iuris executionem, quia de se certum est, et perito potest clare constate ex deductis hinc inde, qualis debeat sequi sententia, ergo non videtur posse allegare a modo questionem vel differentiam superesse inter partes, saltem talem que causare possit compromissum, quia dubietas solum iuris non aprat viam compromisso."

61 Ibid., fols. 176v-177r.

62 This statute ended with the observation, however, that "possit tamen talis in praedictis executionem, usu, allegatione, productione dicti laudi uti iure communi, et eius benefitio" (Statuta, 168).

63 Slightly different terms applied to notifying those living outside Florence and outside her territory.

64 Cf. Christiane Klapisch-Zuber, “'Kin, Friends, and Neighbors': The Urban Territory of a Merchant Family in 1400," in her Women, Family, and Ritual in Renaissance Italy, trans. Lydia Cochrane (Chicago 1985), pp.85-86, which examines in detail $l$ libro degli affari proprii di casa di Lapo di Giovanni Niccolini de'Sirigatti, ed. Christian Bec (Paris 1969); and examples in Pierre Hurtubise, Une famille témoin: Les Salviati (Vatican City 1985), pp.50, 85. Also see my Emancipation in Late Medieval Florence (New Brunswick 1982), pp.72, 105-106, 110-122.

$65 \mathrm{I} \mathrm{am}$ in the course of preparing for publication the results of a limited preliminary survey into a number of arbitrations from early fifteenth-century Florence.

66 Niccolini, p.142.

67 Cf. Lauro Martines, Lawyers and Statecraft in Renaissance Florence (Princeton 1968), pp.406408; Anna Maria Enriques, "La vendetta nella vita e nella legislazione fiorentina," Archivio storico italiano 91 (1933), pp.85-146, 181-223.

68 Niccolini, pp.131-132.

69 Ibid., p.134.

70 ASF, Notarile antecosimiano G212 (1422-1429), fols. 378r-379r. Ratification cam at a different site, the palace of the Mercanzia, so presu mably Salamone missed the proceedings to attend to business there. Also presumably he know in advance what the settlement would be. The transfer of ownership to his sister may have been an elaborate fiction (see below).

71 Two examples: "Ricordo chome insino d'aghosto 1483 Ghuido di Francesco Baldovinetti peruna parte, Giovanni e Piero di Ghuido Baldovinetti dal' altra parte feciono chonpromesso gienerale in quale chonpromesso si fecie in Ghuido Chanbi nostro parente, e il detto Ghuido Chanbi lod di ditto mese e anno, e lod in questo modo che poderi di Chalicharza fussono di piero e di Giovanni pernon divissi, e d'achordo Ghuido e Piero e Giovanni ratifichorno e Ghuido di Francesco Baldovinetti di nuovo don ogni ragione avessi insu detti poderi e di tutto fu roghato ser Machario di ser Andrea Machalli ista al podestà di Firenze" (ASF, Acquisti e Doni 190/3, Ricordanze di Giovanni di Guido Baldovinetti [1476-1496], fol. 13r.)

"Onde che poi a di 2 di dicembre 1409 per buon rispetti e per consiglio del detto ser Vanni, Giovanni di Maffeo sentenzi che il detto Barna non mi potesser chiedere né adomandare parte che gli tochasse o potesse gli pervenire della dota di monna Tessa sua madre e mia donna che fu né eziandio gli usufrutti alla mia vita tanto e piú che tutte chose e ragioni donateli per manceppagione o per altro modo, e non possa adomandare o altri per lui ma 


\section{6 / Renaissance and Reformation}

debbano ritornare al ceppo e nel mio albitrio e promisa la difesa etc. e non ven'incontro ec. e pienamente sa con ci in questo effetto di tutto fu rogato il sopradetto ser Matteo Mazetti per ben di Barna e degli altri" (ASF, Manoscritti 77, Vari di casa Curiani, fol. 34v).

72 Inlibro di ricordanze dei Corsini, ed. Armando Petrucci (Rome 1965), pp.75-76. Only in 1428 did Neri finally die and even then usufruct went to his illegitimate son Sandro by an agreement worked out with Matteo's sons and codified into the form of a laudum with two other Corsini as arbiters (ibid., 129).

73 ASF, Carte strozziane, 5th ser., 1750, Ricordanze di Bartolomeo di Tommaso di Federigo Sassetti, fol. 182r: "Ricordo come insino a di vi di marzo 1436 Federigo di Tommaso Sassetti da una parte e io Bartolomeo dal' altra parte faciemo gienerale conpromesso in Domenicho di Filippo Tochini nostro cognato...

"A dì 19 del detto mese di marzo 1436 il detto Domenicho lod e giudic che il podere da Nnobili di detto Federigo fusse di me Bartolomeo, presente il detto Federigo e ciascuno di noi notific al detto lodo...

"Il detto lodo si diede a cautela perché il detto Federigo avea debito assai in comune per li sue graveze e perché io lo difendessi et cosi feci mentre che io potei e delle volte gli assegnai conto come e sue cose sicome pe' nostri libri vecchi apariscie."

And fol.204r: "In questo libro 182 e 183 aparisce nel modo che io ebbi il podere da Nnobili et simile come di poi ancora mi fu confermato per uno lodo dato a di 31 di luglo 1446, rogato per ser Agnolo di Piero da Terra Nuova, siché non me ne pu essere dato diú inpaccio. Bene è vero che Federigo mio fratello me lo volle torre con dire che io avessi promesso di rendeglele a sua posta. Questo non fu mai vero né verisimile, in per che avendoglele i' promesso v'arebbe voluto chiareze di mia mano come velle quando me ne fece carta nel anno 1436, perché io glele salvassi dalle graveze com' apare in questo 182 rogato..."

Interestingly, Sassetti also noted that the property division worked out by arbitration between him and his other brother, Francesco, had to be revised a year later: "per la divisa fatta dirinpetto si restava a chiarire alchuna cosa fra noi" (fol. 181r).

74 Ricordanze dei Corsini, pp.125, 131-132.

75 Niccolini, pp.107-108.

76 Ibid., p.121.

77 Cf. my "Multorum Fraudibus Occurrere: Legislation and Jurisprudential Interpretation Concerning Fraud and Liability in Quattrocento Florence," Studi senesi 93 (1981), pp.318, 325-329, 330-332.

78 BNF, Principale, II, iv. 435.

79 Sella, 210, notes that the rule was that there could be no move to arbitration after formal litis contestatio, so Bencivenni must have had in mind an exchange of arguments prior to both parties agreeing to leave decision to a designated judge.

80 BNF, Principale, II, iv, 435, fol. 53v: "In ver<bum> "ac si instrumentum guarentigiatum." Sed instrumentum guarentigiatum non potest executioni mandari in persona debitoris nisi post terminum certum in instrumento contentum et terminus expressus in laudo currit demum a die notificationis ut in precedenti statuto de notificatione laudi. Ergo videtur quod terminus contentus in laudo non sit certus et per consequens debeat fieri requisitio ut instrumento guarentigiato continente terminum incertum, et ita consuluit dominus Nellus in causa fratris cugini Francisci Neri sub aliis terminis. Sed contrarium fuit iudicatum per dominum Andream de Fulgineo collateralem domini Francisci de Ancona, et bene quia terminus laudi est declaratio compromissi guarentigiati."

81 BNF, Panciatichiano 138, fols. 205r-206v.

82 Sella, chap. 11, treats the consilium sapientis and arbitration in the same chapter.

83 Here the consultative jurist was theoretically neutral, in distinction to composing a consilium "pro parte" for use by one party in bolstering its case.

84 The procedure of appointing a judicial (vs. advocatory) sapiens and rules governing him were laid out for Florence in the statute "De modo procedendi in civilibus" and others. Also cf. Luigi Lombardi, Saggio sul diritto giurisprudenziale (Milan 1967), pp.79199. 
85 Cf. Helmholz, Marriage Litigation, 137, 162: Engelman, et al., 14-17; Guido Rossi, Consilium sapientis iudiciale: Studi e ricerche per la storia del processo romano-canonico (Milan 1958).

86 In one instance. the parties to a very complex inheritance division enlisted the services of a jurist. Torello Torelli (fl. 1400), as arbitrator to oversee the division. With the aid of the parties and the text of the will in question. Torelli extracted a list of eight legal questions and submitted these to three colleagues. Paolo di Castro, Nello da San Gimignano, and Alessandro Bencivenni. On 10 October 1415 they wrote up a determination, relatively informal compared to a full-fledged consilium, and Torelli then simplyembraced their findings as his laudum.

The case is copied in BNF, Landau Finaly 98, fols. 129r-139r. The three jurists'opinion utilizes legal citations, but it deals successively with the eight issues in a brief manner and without the pro-et-contra style that was so well suited to formal litigation.

87 BNF. Landau Finaly 98. fols. 355r-360r (new numeration). Quote on fol. 355r. This text will be referred to hereafter as Consilium.

88 As spelled out in "De modo procedendi in civilibus" (Statuta, 1: 109-115) and Bencivenni's treatment of it, BNF, Principale, II, iv, 435, fols. 1r-9v.

89 Cf. Martines, p.499, but also 107 and 302.

90 Ibid., pp. $408-409,416,420$ n. 47.

91 Gene Brucker. The Civic World of Early Renaissance Florence (Princeton 1977), pp.313 n. $307,484$.

92 Consilium, fol. $356 \mathrm{v}$.

93 Ibid., fol. 357r.

94 Bartolo to D. 4.8.2 (Venice 1585), fol. 145ra.

95 Ibid., fol. 147rb; Consilium, fol. 357r.

96 Martone, pp.166-167.

97 Ibid., p.168.

98 Paolo di Castro, Consilia (Venice 1580), vol. 1, cons. 462, fol. 237ra: "Laudum tamquam iniquum, et enormem laesionem continens in dicta parte debet reformari non obstantibus renunciationibus et statutis."

99 Consilium, fol. $357 \mathrm{v}$.

100 Baldo to D. 28.7 .7 (Venice 1577), fol. 102ra.

101 lbid.

102 Ibid., fol. 358r.

103 Baldo, Super pace Constantie, in ver. sententie quoque, in Super feudis restauratum comentum (Pavia 1495), fol. 93vb: "Respondeo tales sententie valent pro rebus compromissis sed extra compromissum non valent etiam si post compromissum nominatim emologetur laudum, nam expresse dicit decretalis quod non potest emologari laudum super quo non procedit compromissum, extra de confir. uti. vel inuti. c. examinata [X. 2.30.7] ... nam ubi non procedit notio ibi sententia non procedit." Nello almost immediately cites the decretal Examinata also: Consilium, fol. 358r.

104 Angelo degli Ubaldi, Consilia (Frankfurt 1575), cons. 42, fols. 26vb-28ra, cons. 218, fols. 146ra$147 \mathrm{va}$. Angelo did concede latitude to deal with consequences of the resolution of the basic issue, as in setting performative conditions of compliance (cons. 42).

The "general" nature of arbitration was relied on, however, by Sallustio Buonguglielmi (1373-1461) and two colleagues in a later case (BNF, Magliabechiano xxix, 193, fols. 172r178r). There the arbitrators had issued two lauda; one establishing a monetary compensation (termed interesse) for what seems to have been a murder, the other enjoining both sides to maintain peace. The second laudum was affirmed to be in the competence of the arbitrators because all parties were out to preclude vendetta, which had to be presumed (according to the subsequent unsigned consilium, fols. $281 \mathrm{r}-284 \mathrm{v}$, which upheld the first laudum but not the second, on the ground that it had not been properly notified to the parties, "secundum comunem usum et comune vivere" offended persons considered vendetta, for not to do so would be toneglect their fama, and "qui negligit famam suam est sui interfector unde sicut non sunt 


\section{8 / Renaissance and Reformation}

domini suorum corporum" [fol. 284r]): "Further these words work the effect that it must be had as if express mention was made of an article of peace, which is proved not only from the words of the compromissum but by reason ... it follows that the parties wanted to come into compromise all of which should be arbitrated as if special mention was made. Therefore virtually it can be said that express mention was made of an article of peace." The establishment of a compensatory sum in the first laudum was also upheld: "This interpretation is to be followed as more benign and as favorable in practice to the republic and as avoiding that scandals might multiply, and even as customary in the city of Florence as is asserted to ine."

105 Ibid., cons. 172, fols. 111 rb-va.

106 Bartolo to D. 29.1.24 (Venice 1581), fol. 140ra-rb.

107 Consilium, fol. 358v.

108 Baldo to D. 28.7 .7 (note 100 above) and Bartolo to D. 28.7.8,4 (Venice 1581), fol. 136va.

109 Consilium, fol. 359r.

110 Ibid.

111 (Venice 1585), fols. 146va-147rb.

112 Consilium, fol. 359v.

113 Bartolo, fol. 147rb.

114 Consilium, fol. 360v.

115 Angelo, cons. 343, ed. cit., fol. 244rb: "quia natura arbitrii hoc est, quod libera arbitrii sit facultas, quam sententiam ferre velit."

116 Nelson, "Dispute Settlement in Carolingian West Francia" (note 13 above), takes the opposite opinion as to what sorts of issues were more susceptible to processing in the different procedures. My own research in Florentine arbitration records tends to substantiate the viewpoint stated here. It is true many lauda arose between kin (as seen from examples mentioned herein), but on the issue of property most often. I will publish some of this research soon. Here I would also point out, however, that this is also a false dichotomy in that one's claim to be a kinsman rests on and is embodied in property. Most any issue could be rendered, however arbitrarily, as a matter of property, so Nelson`s distinction between property and relationship, though widely shared in social-legal analysis, is not totally meaningful in the end.

117 The problem with an anthropological approach that looks only at the structure of arbitration or litigation and derives its function therefrom is that it fails to mount an historical perspective, to observe the process work itself out. The process malfunctioned in the case we have been considering, at least further steps were necessary after arbitration.

118 According to Rene David, French Law: Its Structure, Sources, and Methodology, trans. Michael Kindred (Baton Rouge 1972),p.46, arbitration currently precludes appeal based on "errors of law," by which he seems to mean procedural technicalities. The laudum Nello overturned was contested on wider issues of right and competence.

119 Sally F. Moore, "Political Meetings and the Simulation of Unanimity: Kilimanjaro, 1973," in Secular Ritual, ed. Sally F. Moore and Barbara G. Myerhoff (Amsterdam 1977), p.153: "Formality in such contexts can convey the message that certain things are socially unquestionable (the secular equivalent of the sacred) and by so declaring in such a form, formality helps to make them unquestionable. The public making of choices implies a certain situational uncertainty, a degree of indeterminacy and openness in the social reality. Institutionalizing the settings in which the choices are made, and formalizing them decreases the amount of openness. It 'domesticates' the indeterminate elements in the occasion by surrounding them with fixed forms."

120 Martone,p.184: "L'attività dei giureconsulti pratici in questocampo fu in concreto sollecitata da prevalenti e pressanti interessi clientelari. Furono, in definitiva, le esigenze delle parti inadempienti a stimolare una linea interpretative sempre piú lontana dal dettato statutario. Di front alla rapidità irrituale imposta dal legislatore cittadino, i giuristi si provarono, cosí, ad introdurre tutti $i$ gravami e tutte le lungaggini proprie dei riti orginari." 
121 Cf. Norbert Horn, 'Aequitas' in den Lehren des Baldus (Cologne 1968); Mario Sbriccoli, L'interpretazione dello statuto: Contributo allo studio della funzione dei giuristi nell'età comunale (Milan 1969).

122 Andrew Arno, "A Grammar of Conflict: Informal Procedure on an Island in Lau, Fiji," in Access to Justice, vol. 4: The Anthropological Perspective: Patterns of Conflict Management: Essays in the Ethnography of Law, ed. Klaus-Friedrich Koch (Milan 1979), p.44. Also on this theme see John Comaroff and Simon Roberts, "The Invocation of Norms in Dispute Settlement: The Tswana Case," in Social Anthropology and Law, ed. Ian Hamnett (London 1977), pp.77112.

123 Cf. Roberts, “The Study of Dispute," p.19.

124 Cf. John Domaroff and Simon Roberts, Rules and Processes: The Cultural Logic of Dispute in an African Context (Chicago 1981). They also provide (pp.221-224) an interesting discussion of intrafamilial disputes, especially between brothers, that has some resonance for the case we have discussed here.

125 Wickham, "Land Disputes," p.123; see also Wormald, "The Sandlaw Dispute," p.205.

126 Cf. Richard L. Kagan, "A Golden Age of Litigation: Castile, 1500-1700," in Disputes and Settlements, pp.145-166; Marc Galanter, "Why the 'Haves' Come Out Ahead: Speculation on the Limits of Legal Change," Law and Society Review 9 (1974), 95-160.

127 Comaroff and Roberts, "Invocation of Norms," 82-83.

$128 \mathrm{Cf}$. Lynn Mather and Barbara Yngvesson, "Language, Audience, and the Transformation of Disputes," Law and Society Review 15 (1980-81), 775-821.

129 Cf. Miller, "Avoiding Legal Judgment," p.101.

130 Ibid., pp.113-114. 